\title{
SALAMİS KENTİ ROMA HAMAMI
}

\section{Aytaç COŞKUN}

\author{
Anahtar Kelimeler: Kibrıs • Salamis • Roma • Hamam • 3D Rekonstrüksiyon \\ Keywords: Cyprus $\bullet$ Salamis $\bullet$ Roman $\bullet$ Bath $\bullet$ 3D Reconstruction
}

\section{Özet}

Salamis Roma Hamamı'nda 2000 yılında başlatılan kazı çalışmaları yapının mimarisi, bölümlerin işlevi ve planlamasına yönelik yeni bilgiler ortaya koymuştur. Hamam kentin kuzey kesiminde kamu binalarının bulunduğu yeni merkez içerisinde hamam-gymnasium, amphitiyatro, tiyatro ve stadion yapıları ile birlikte yer almaktadır. Salamis Hamamı'nın hangi tarihte inşa edildiği konusunda bize kesin bilgi verebilecek yazılı belge bulunmamasına karşın, yapıyı planlama ve mimari özelliklerine, duvar işçiliğine, kazılarda ele geçen küçük buluntular ve yazıtlara göre tarihleyebiliriz. Hamam M.S. 2. yüzyllın ilk yarısında Traian ya da Hadrian Dönemi'nde inşa edilmiş olmalıdır. Salamis Hamamı'nın, kentteki diğer kamu yapıları gibi şehre büyük zarar veren M.S. 332 ve 342 yıllarındaki iki büyük deprem sonrası büyük oranda onarıldığ1 anlaşılmaktadır. Hamamın M.S. 647-648 yıllarındaki Arap istilalarına kadar kullanıldığı da kazılarda ele geçen buluntularla desteklenmektedir.

\section{Abstract: The Roman Bath at Salamis, Cyprus}

Salamis was one of the most prosperous cities of Cyprus during the Roman period. The city's wealth was evidently derived from its location on a strategically important point within the eastern Mediterranean trade network. Archaeological excavations resumed at Salamis in 1998 under the leadership of Prof. Dr. Coşkun Özgünel from the Ankara University increased our archaeological knowledge on this important city. These archaeological excavations conducted by the Turkish team currently concentrate on the Roman remains at Salamis. Among these Roman remains, attention has also been placed upon the poorly understood bath structure in the course of field studies between 2000 and 2005. However, it is the recent studies carried out by the Turkish team that helped to identify the units of this Roman bath, including praefurnium, storage room, caldarium, two tepidaria, an intermediate space, frigidarium, and apodyterium. The bath is located in the northern part of the city where numerous large-scale public buildings such as bath-gymnasium, theater, amphitheatre and stadium are found.

Bath is architecturally formed of five horizontally adjoining parallel rooms, to which furnace and storage units are annexed from the northern side. It is clear that whoever comes to the Salamis bath first enters into the changing room (apodyterium) before reaching to tepidarium I where a shallow water basin occurs in the center for cleaning the feet. Niches also occur on the walls to clean up the dirt and oil in this room. This warm unit is evidently a place where one adapts himself to the hottest room, which is caldarium. It is likely that those who could not adopt themselves to the 
hottest room (caldarium) take their baths in the tepidarium II. The last room visited is the frigidarum, where the visitors spent the most time was spent after caldarium. It is well known that in these rooms, in particular at the frigidarium, leisure activities take place. Visitors leave the bath after using the cold-water pool located in the frigidarium.

The classifactory scheme developed for the plan type of the Roman baths by Krencker has still widely been accepted by the archaeologists dealing with the baths. According to this classification based on the plan types, the Salamis bath may fall into the "row type", which is characterized much by a row of vaulted units of apodyterium, frigidarium, tepidarium and caldarium. In this order, anyone who wishes to enter into the bath from apodyterium leaves the building from the same room by crossing the same rooms in order to reach the changing room before exit. Although this type of baths has also been named as the "Pompeian type" and the earliest examples are found at Pompeii, this type was widespread during this period.

There is no literary evidence for an absolute dating of the Salamis bath. However, a relative date can be offered for the bath by examining the wall techniques, planning, small finds recovered during the excavations, and the inscriptions. This enables one to estimate how long the bath was used by the Salaminians. In terms of plan, no examples identical to that of Salamis are found in Italy and in Roman provinces in Greece, northern Africa, and Asia Minor. However, it can be compared to those early examples at Pompeii in Italy, as well as those found in Lycia, Pamhpylia and Cilicia. It is clear that those Stabian and Central baths at Pompeii served as models for numerous examples found in both Italy and Roman provinces. Nevertheless, it may be stated that the plan of the Salamis had some other local features as well. The Salamis bath particularly resembles the first and second century A.D. examples in terms of planning. Despite the recovery of two inscriptions dating to the second and third centuries A.D., we do not have evidence to purpose an absolute date for the bath. Eastern sigillata A and B wares of the first and second centuries A.D., typical Palestinian and Cypriot cooking vessels of the first to third centuries A.D., and numerous lamps dating from the first to the end of the second century A.D., which were found in the excavations carried out at the furnace and storage room, all constitute the most important evidence for obtaining a relative date for the Salamis bath. Besides these early finds, examination of the wall techniques of the bath also points to the early use of the structure. In particular, the wall technique of this bath can best be compared to the Bath-Gymnasium Complex re-built nearby during the reigns of the Roman Emperors Trajan and Hadrian.

We know from the inscriptions found at Salamis that, following a severe earthquake in 76-77 A.D., there were intensive rebuilding activities at the city during the reigns of Trajan and Hadrian who both favored this Cypriot city for some reason. The inscriptions also mention that Hadrian was venerated and declared as the protector of the city because of his donations and helps he offered for the rebuilding of the city. The Hellenistic bath-gymnasium complex became insufficient in fulfilling the needs of the growing population of city during the reigns of Trajan and Hadrian, a period when the public monuments such as theater, amphitheatre, stadium and palaestra were also enlarged in size as a result of population increase. As a result, it was deemed necessary to build a new bath during this period.

The Salamis bath was renovated to a great extent following the two major severe earthquakes of 332 A.D. and 342 A.D. Most of the architectural evidence for this bath at Salamis belongs to the period following these earthquakes. This is to say that the available evidence represents the second phase of this bath's use. Those tiles and stamped tiles, lamps and pots, coins dating to the reign of the Byzantine Emperor Heraclius (610-641 A.D.) recovered during the excavations indicates that the bath was continued to be use following the major earthquake of 342 A.D. Traces of alterations, 
general architectural traits, and the general features of opus sectile found there may all be used to as evidence to demonstrate the use of bath until the period of Arab invasions in 647-648 A.D.

1890 yllindan bu yana bilinen ${ }^{1}$, İngiliz araştırmacılar tarafindan oldukça düzensiz, gelişigüzel çok az bir kısmı kazılarak kaderine terk edilmiş olan Salamis'deki Roma Hamamı'nda 2000 yılında başlatılan kazı çalışmaları, 2005 yılına kadar sürdürülmüşs ; bu çalışmaların sonucunda, Salamis'de yer alan ve kazılardan önce tamamen anlamlandırılamayan hamamın mimari yapısı, bölümlerin işlevi ve planlamasina yönelik praefurnium (külhan) ve depo, caldarium (sıcaklık), iki tepidarium (1l1klık), soğuk bölümlere açılan bir mekân ile birlikte frigidarium (soğukluk) ve apodyterium (soyunma odas1) olarak öngörülen bölümler ortaya çıkarılmış, yapının kapladığ1 alan $1764 \mathrm{~m}^{2}$ olarak hesaplanmıştır (Harita 1, Plan 1, Res. 1-2) ${ }^{3}$.

Kentin Hellenistik Dönem'den itibaren kuzeye kayması sonucunda oluşan yeni merkez içerisinde hamam-gymnasium ${ }^{4}$, tiyatro ${ }^{5}$ ve stadion gibi kamu yapıları yer almaktadır. Kentte kazilar yapan Jeffery tarafindan da bahsedilen Roma Hamami ${ }^{6}$ bu kamu binala-

1 Kentteki İngiliz kazıları sonrası hamam, kent planında gösterilmiş, fakat yap1 hakkında bilgi verilmemiştir: Munro - Tubbs 1907, 59 vd.

2 Öncelikle kentin bu önemli kamu yapısını yayınlama olanağı tanıdığı için hocam Coşkun Özgünel'e; bu çalışmayı sağladığı burs ile maddi olarak destekleyen Akdeniz Medeniyetleri Araştırma Enstitüsü’ne (AKMED); 2 ve 3 boyutlu çizimlerde büyük yardımlarından dolayı mimar Bora Işık’a teşekkürlerimi sunuyorum.

3 Bu hesaplamada sadece hamamın işlevsel mekânlarının kapladığı alan dikkate alınmış, gezinti alanı bu hesaplamaya dahil edilmemiştir.

4 Karageorghis 1969, 185-193; Karageorghis 1970, 7-10.

5 Karageorghis 1962, 396-405, Karageorghis 1963, 52-55; Karageorghis 1970, 10-12.

6 Kentte 1924-1925 yillarında kazilar yapan Jeffery tarafindan 1926'da Salamis için hazırlanan rehber kitapta, söz konusu Roma hamamindan bahsedilmektedir. Jeffery'nin tanımlamasına göre hamam sıra halinde uzanmış üç dikdörtgen bölümden oluşmakta ve bunlar- rının bulunduğu yeni merkez içerisinde, tiyatronun $100 \mathrm{~m}$ batısında güneydoğukuzeybatı doğrultusunda uzanmakta ve yapı Vitruvius'un da hamamlar için önerdiği en sıcak konum olan güneybatı yönüne bakmaktadır (Res. 1-2)

Salamis Hamamı'nın konumu göz önünde bulundurulduğunda, yapıdan yola çıkarak bir hamamın inşası için, yer seçimindeki tercih sebeplerini sıralamak gerekirse $^{8}$, bunlardan ilk göz önünde bulundurulacak husus kuşkusuz elverişli büyüklükte bir alanın mevcudiyeti ve buranın antik çağın su taşımacilığına uygun seviyede olmasıdır?. Bunun yanı sira bir hamam için zorunlu olan yakacak sağlanmasındaki kolaylıklar da düşünülebilir. Orman içinde yer alan bir kentte bu bir sorun değildir, fakat şu da bir gerçektir ki esir kullanımının en üst düzeyde olduğu bir dönem için yakacağa yakın olmak yer seçimini etkilemediği de düşünülebilir ${ }^{10}$.

dan merkezde olan bölümün apsisli olduğundan söz etmektedir: Jeffery 1926; Guide 1970, 16.

7 Vitruvius, hamamlar için öncelikle mümkün olan en sıcak konumun seçilmesi gerektiğini ve bu yönün kuzey ve kuzeydoğu dışında seçilmesini, sıcak ve 11 k hamamların güneybatıdan ışık alması veya konum buna elverişli değilse 1şı̆̆ın güneyden gelmesi gerektiğini; çünkü genellikle yıkanma zamanının gün ortasından akşama kadar olduğunu belirtmektedir: Vitruvius, V, 10, 1.

8 Bayburtluoğlu 2003, 127.

9 Salamis Roma hamamı için ayrı bir su taşıma sistemi inşa edilmemiş, hamam-gymnasium'a su sağlayan aquadükt kullanılarak, bu sayede işçilikten ve masraftan tasarruf edilmiştir. Hamam inşasında bunun da göz önünde bulundurulduğu düşünülebilir.

10 Buna en güzel örneği özellikle ağaç yönünden fakir olan yörelerdeki hamamlar teşkil ederler. Ankara'daki Caracalla Hamamı büyüklüğü ile olduğu kadar yakacak kaynaklarına uzaklığı ile hemen akla gelen örneklerden biridir. Yapının kullanıldığı dönemde Kıbrıs adası için yakacak sıkıntısı olmadığı söyle- 
Yer seçimindeki diğer bir sebep estetik kaygılardır ve günümüzde olduğu gibi Antik Dönem'de de şehir yöneticilerinin veya kent halkının, şehirlerini güzel ve düzenli göstermek çabasında oldukları muhakkaktır. Bu yüzden yapılar gelişigüzel inşa edilmemekte ve yapıların yerleşiminde estetik olgular da göz önünde bulundurulmaktadır. Hamamlar genelde manzarası güzel olan alanlara kurulmakta ve böylece hamama gelenlerin etrafi izlemesi de sağlanmaktadır ${ }^{11}$. Hamam yapılarının aynı zamanda ulaşım yollarına yakın olması gerektiği de düşünülürse ${ }^{12}$ söz konusu yapının $40 \mathrm{~m}$ doğusunda hamama paralel uzanan ve ilk evresi Roma Dönemi'ne tarihlenen kentin ana caddelerinden biri yer almaktadir" ${ }^{13}$ Caddenin kuzey ucunda "Kuzey Kapısı" olarak adlandırdığımız kesme blok taşlardan inşa edilmiş dört yöne geçişi sağlayan bir kap1 yer almaktadır ki bu kap1 hamam-tiyatro arası bağlantının yanı sıra güneydeki sivil yerleşimlerin bulunduğu alandan kuzeydeki gymnasium, tiyatro, stadion, hamam gibi kamu yapılarına ulaşılmasını sağlayan bağlantıdır ${ }^{14}$. Bu nedenle cadde ile

nebilir, zira M.Ö. 64 - M.S. 21 yılları arasında yaşayan Strabon, antik dönemde Kibris'in orman yönünden zengin olduğunu belirtmektedir: Strabon XIV, VI, 2, 5.

11 Salamis Hamamı'nın doğusunda yer alan gezinti alanı, caddeye, kot olarak hamamdan yüksekte olan stadion'a ve tiyatroya bakmaktadır ki, bu manzara muhtemelen hamama gelenler için bir göz zevki oluşturmaktadır. Salamis Hamam-Gymnasium kompleksinde ise yapının sıcak mekânları denize bakmaktadır.

12 Liman kentlerinde, limanın yakınında yolcu ve tüccarların temizlik ve dinlenme ihtiyacını karşılayan hamamlar yer almaktadır. Bu göz önünde bulundurulduğunda limana bağlanan bir yol ile Salamis Hamamı da kullanılmış olmalıdır. Bu tip hamamlara örnek Side, Miletos ve Ephesos verilebilir.

13 Öztaner 2007, 293 vd.

14 Kentte iki hamamin arasında yer alan tiyatro ve stadion'un yönlenmesi ve konumunun, kentteki iki hamamla bağlantılı olduğu da düşünülebilir. Çünkü hamamlardan çıkan yoğun dumanın buradaki gösterileri ve izleyicileri engellememesi gerekmektedir. Sözünü etti- bağlantılı olması gereken hamamın girişi, doğu yönde olmalidır ve tek bir kapı aracllığ1 ile giriş sağlanmaktadır (Res. 3-4) ${ }^{15}$.

Salamis Hamami, birbirine paralel ve bitişik olan beş ana bölümden oluşmaktadır ki, bu bölümlere bağlı külhan (Res. $14-15)^{16}$ ve depo kism1 (Res. 16) ${ }^{17}$, yapiya dik olarak birbirine paralel yapının kuzeyinde, caldarium'a bitişik olarak düzenlenmiştir. Salamis Hamamı'na gelen kişi ilk olarak apodyterium' $\mathrm{da}^{18}$ soyunduktan sonra

ğimiz bu kamu yapıları inşa edilirken muhtemelen bu etken de göz önünde bulundurulmuş olmalıdır.

15 Söz konusu yapıda, gerçekleștirilen kazılar sonrası frigidarium'da dahil bir girişe rastlanmaması nedeniyle, giriș kapıs1, henüz kazılmayan apodyterium bölümünde olmalıdır; çünkü hamamlara giriş genelde soyunma odasından sağlanmaktadır.

16 Dokuz basamak ile inilen pişmiş toprak tuğlalardan örülmüş Salamis Hamamı'ndaki külhan, yapının güneydoğusunda yer almaktadır ve söz konusu yapıda gerçekleştirilen kazılar sonrasında tek külhana sahip olduğu tespit edilmiştir. Külhan, $1 \mathrm{~m}$ genişlik ve 1,60 m yüksekliğe sahip bir kemerle başlamakta; bunun gerisinde pişmiş toprak tuğlalarla yapılmış 0,50 $\mathrm{m}$ yükseklik, $0,33 \mathrm{~m}$ genişlikte asıl ateşin yakıldığ yerden oluşmaktadır. Külhanın ağız kısmı, kolaylıkla kapatılabilmesi için dar tutulmuştur. Külhan buradan bir kanal ile caldarium'a bağlanarak, hypokaust ve tubuli sistemi ile bütün sıcak mekânların ve kazanlardaki suyun ısınmasını sağlamaktadır. Külhanın ateşini yakan, 1sısın kontrol eden görevli ise dar bir alanda hareket etmek zorunda kalmıștır. 3,98 x 10,25 m boyutlarında külhan bölümü iki mekândan oluşmaktadır. İlk mekân ateşin yakıldı̆̆ı asıl yer, diğer mekânda hamamın isıtılmasinda yakıt olarak kullanılan odunların istiflendiği depolardan birisidir.

17 Külhanın hemen batısında depo olarak kullanıldığı düşünülen mekân $6,35 \times 10,25 \mathrm{~m}$ boyutlarındadır. Bu mekânın 3,30 x 3,50 boyutlarında hem dişarıya hem külhana açılan karşılıklı iki büyük kapısı bulunmaktadır ve bu kapıların geniş olması depolanan odunların büyüklüğü nedeniyle geçişi kolaylaştırmak için olmalıdır.

18 Yapıda gerçekleștirilen kazılar sonrası, frigidarium bölümünün kuzey duvarında, başka bir mekâna açllan bir diğer kapı olduğu ve doğu duvarın devam ettiği görülmüş, bu sayede bir kısmı açılan frigidarium bölümünün paralelinde başka bir mekânın olduğu tespit edilmiştir. Bu mekân, muhtemelen hamamin soyunma odası olabileceği gibi, henüz tespit edilemeyen hamama giriş doğudan bu bölüme olmalıdır. 
tepidarium I'e (Res. 8-9) ${ }^{19}$ geçerek buradaki sığ havuzda ayaklarını temizlemekte, nişlerde yıkanarak yağ ve kirlerden arınmakta, vücudu burada sicağa hazırladıktan sonra, fazla sıcağa dayanıksız kişiler tepidarium II'de (Res. 10-12) ${ }^{20}$, dayaniklilar ise caldarium'da (Res.

19 Hamamin 6,5 x 21,45 m boyutlarındaki tepidarium'un doğu kısmında 6,5 x 7 m'lik bir alan kazılarak mekânın üçte bir kısmı açığa çıkarılmıştır. Bölümün orta kısmında, sığ bir ayak yıkama havuzu yer almaktadır ki bu havuz 3,29 m genişliğe ve henüz açılmış kısmıyla 2,3 m’lik uzunluğa sahiptir (toplam uzunluğu yaklaşık $7 \mathrm{~m}$ olmalıdır). $0,165 \mathrm{~m}$ derinliğe sahip bu sığ havuzun kenarlar1 dışa doğru yaklașık $45^{\circ}$ lik bir eğime sahiptir. Havuzun tabanı, mermer plakalarla ve opus sectile'lerle kaplanmıştır. Tepidarium I'de, caldarium ve tepidarium II'de olduğu gibi hypokaust ve tubuli sisteminin kullanıldı̆g tespit edilmiştir. Batı duvarı apsidal bitimli olan tepidarium II'nin aksine, henüz kazılmamış olmasına karşın tepidarium'un batı duvarının düz bir şekilde inşa edildiği görülebilmektedir. Ayrıca bölümün tepidarium II ile bağlantısını sağlayan doğu kapisının 1,47 $\mathrm{m}$ doğusunda kap1 ile aynı boyutlarda bir nişin varlığı tespit edilmiştir. $\mathrm{Bu}$ niş temizlenme amaçlı kullanılmış olmalıdır ve bölümün toprak altındaki batı kısmında da aynı nişten bulunması olasıdır. Mekânın doğu duvarında frigidarium'a geçiş kapiları yoktur ve tek geçiş doğudaki 3,06 x 3,60 m boyutlarında küçük bir mekân ile sağlanmaktadır (Res. 7). Bu mekân tepidarium ile frigidarium'u bağlayan tek geçiştir ve bu sayede frigidarium'dan gelen soğuk havanın sıcak mekânlara geçişi büyük ölçüde engellenmiştir. Tepidarium I bölümü, tepidarium II'ye güney duvardaki iki dikdörtgen geçiş ile bağlanmaktadır. Bu dikdörtgen geçişler, caldarium ile bağlantıyı sağlayan tonoz geçişlerle aynı aksta değildirler.

20 Tamamı ortaya çıkartılmış 10,5 × $24 \mathrm{~m}$ boyutlarında ikinci tepidarium un batıs bir apsis ile sona ermektedir. Hem apsis içerisinde ve hem de doğu uçta olmak üzere, bölümde iki havuz bulunmaktadır. Mekânın doğu kısa kenarında 2,25 x 8,15 m ölçülerinde ve 1,14 m derinliginde dikdörtgen havuz; batı ucunda yer alan apsisin içerisinde ise, aksı güney kenara doğru kaymış yarım yuvarlak formlu havuz yer almaktadır. Havuzun ön yüzü $6,80 \mathrm{~m}$, orta kısmındaki genişliği ise 4,40 m olmakla birlikte $1,10 \mathrm{~m}$ derinliğe sahiptir. Havuzu çevreleyen apsis kısmında yıkılmış olmalarına karşılık üç adet nişin varlığı görülebilmektedir. Bölümün içini dolduran tonoz çat1 dolgusunun kazısı sırasında, 4,5 x 2,5 m boyutlarındaki çatıya ait harçlı masif bir kütlenin üzerinde in situ durumda üç adet çatı kiremidinin mevcut olduğu görülmüştür. Tonoz çatının harcına direkt olarak yapıștırılmış olan bu kiremitler $0,42 \times 0,52 \mathrm{~m}$ boyutlarındadirlar. $\mathrm{Bu}$ kütlenin hemen batısında yıkıldığı biçimiyle görebildiğimiz ve yoğun olarak kazılarda ortaya çıkarılan, tonoz
13) ${ }^{21}$ yıkanmaktadırlar. Sicak havuzlarda ve nişlerde y1kanma işleminden sonra en son uğranılan bölüm frigidarium' dur $^{22}$ ve

çatıda kullanılmış $0,26 \times 0,42 \mathrm{~m}$ boyutlarında pişmiş toprak tuğlalar ele geçmiştir. Bu tuğlalar dikine yerleştirilerek tonozu oluşturmaktadırlar. Ele geçen beyaz zemin üzerine yeşil ve kırmızı renklerden oluşan basitçe yapılmış floral bezekli fresko parçalarından anlaşıldığı kadarıyla, tonoz çatının alt kısmının söz konusu şekildeki fresko ile süslendiği söylenebildiği gibi, aynı durum buluntular ışığında yapinın tepidarium I ve frigidarium bölümleri içinde geçerlidir (Res. 8-9). Tepidarium II'nin planlama özelliği daha çok caldarium bölümlerinde görülmesine rağmen, bölümün çevresinde yapılan kazılarda, bu bölümü ssıtan ikinci bir külhana rastlanmamıştır. Zira külhanın hem büyük boyutlu caldarium'u hem de bu bölümü aynı derecede 1sıtması zordur, çünkü caldarium'u isıtan sıcak havanın bu bölüme gelinceye kadar 1sısını bir miktar kaybedeceğini söyleyebiliriz. Tepidarium II ile caldarium arasındaki bağlantıyı sağlayan iki adet tonoz geçiş bulunmaktadir.

2115 x 24,5 m boyutlarındaki güneydoğudaki ilk bölüm hamamın en sıcak ve en büyük mekânıdır. Mekânın doğu kısımda yürütülen çalışmalar sonucunda, bölümün kuzey ve güney duvarlarının doğuda içe doğru diş yaparak daraldığ 8,67 x 6,45 m'lik alanda, $7,27 \times 4,40 \mathrm{~m}$ boyutlarında oval bir havuzun yer aldığ1 tespit edilmiştir. Havuz 6,47 x 3,40 m içten içe ölçülere ve $1,40 \mathrm{~m}$ derinliğe sahiptir. Havuzun önündeki döşemenin çöken kısmının hizasında, güney kısımda, hypokaust sistemine doğru inen ve buranın temizlenmesi için kullanılan beş basamak ortaya çıkarılmıştır. Hamamın en büyük bölümü olması dolayısıyla duvarlar kalınlıkları tonozun yükünü taş1yabilmek için yaklaşık 4 m'yi bulmaktadır ve olasılıkla yapının en yüksek olan bölümüdür. Bu mekânın güneyinde külhan kısmı yer almaktadır ve hypokaust ilk olarak bu bölümü 1sıtmaktadır. Bölümün henüz kazılmamış güney kısmında ateşle direk temas halinde hamamin su isıtma kazanları olmalıdır. Su isındıktan sonra sicak su, bu kazanlardan havuzlara, duvarların içinden, söz konusu hamamda da ele geçen kurşun borularla sağlanmaktadır.

22 Genişliği $6,25 \mathrm{~m}$ olarak tespit edilen bölümün açlan uzunluğu 12,40 m'dir (toplam uzunluk 26,09 m). Mekânın kuzey duvarında yer alan kapının $0,50 \mathrm{~m}$ doğusunda kuzey duvara bitişik içten $2,7 \times 3$ m boyutlarında küçük bir havuz ortaya çıkarılmıştır. Isıtma sisteminin olmaması, geçiş mekânının konumu ve heykel kaidesi olabilecek blokların burada ele geçmesi, mekânın hamamın frigidarium bölümü olduğu savını güçlendirirken; henüz kazılmamış alanda, büyük boyutta bir diğer soğuk su havuzunun bulunması da olasilık dahilindedir. 
burada havuzdaki soğuk su ile vücut serinletildikten sonra hamam terk edilmektedir ${ }^{23}$. Hamama gelenler zamanlarının büyük bir kısmını hamamın frigidarium ve caldarium bölümlerinde geçirmektedir ki, bu odalarda özellikle frigidarium'da sosyal, sportif ve gösteriler gibi eğlence aktiviteleri de yapılmaktadir ${ }^{24}$.

Krencker'in Roma Hamamları'nı plan tiplerine göre sinıflandırmasi ${ }^{25}$ hala en kullanışlı ve genel olarak kabul edilen bir methodtur $^{26}$. $\mathrm{Bu}$ sinıflandırmaya göre Salamis Hamamı 'sıra tipi' ne dâhil edilebilir. Bu hamamlarda mekânlar yan yana sırasiyla apodyterium-frigidarium-tepidarium-caldarium olarak düzenlenmektedir ve bu düzenlemede hamama gelen kişi ilk apodyterium'a girmekte, yıkanma işleminden sonra gittiği yönden tekrar geri dönerek yine apodyterium'dan hamamı terk etmektedir. Özellikle bu tip hamamlar Pompeii tipi olarak da adlandirılmaktadir ${ }^{27}$.

Salamis Hamamı'nın planlama açısından kökenini ve benzer özellikler gösteren yap1ları, imparatorluk sinırlarına dahil edilen bölgelerdeki hamamların planlamasında büyük etkisi olan merkezi İtalya ve güney İtalya'daki hamamlarda aramak gerekir ki, bu bölgedeki yapılar incelendiğinde Pompeii'deki Stabian Hamami ${ }^{28}$ ve Merkez Hamam $^{29}$, Herculaneum Forum Hamami ${ }^{30}$,

23 Frigidarium, palaestra'da egzersiz yapıldıktan sonra ilk olarak da kullanila; bilmekteydi: Nielsen 1993, 154.

24 Yegül 1992, 39; Nielsen 1993, 154.

25 Krencker 1929, 177-186; Yegül 1992, fig. 142; Farrington 1995, 18, dn.15.

26 Yegül 1992, 130, dn. 2; Nielsen 1993, 51-52, fig. 1.

27 Yegül 1992, 130, dn. 2.

28 Fiorelli 1875, 161; Nissen 1877, 140 vd.; Maiuri 1942, 70 vd.; De Vos 1982, 194; Brödner 1983, 59; Yegül 1992, figs. 58-59; Nielsen 1993, 7, fig. 79.

29 Krencker 1929, 256; De Vos 1982, 206 vd.; Brödner 1983, 60; Yegül 1992, 63; Nielsen 1993, 8.
M.S. 2. yüzyıla tarihlenen Ostia'daki Neptune $^{31}$ ve Mitra Hamami ${ }^{32}$ birbirine paralel düzenlenmiş bölümleri ve Salamis Hamam'ının planlamasına benzer özellikler göstermesinden dolayı dikkati çekmektedir (Tablo 1). Anadolu'daki Roma Dönemi hamamlar incelendiğinde ise Lykia ve Pamphylia hamamlarında görülen, özellikle Lykia hamamlarının çoğunun 3 ya da 4 dikdörtgen mekânın birbirine bitişik paralel yapılması ve bir nevi vazgeçilmez özelliği olan caldarium'un apsidal bitişli düzenlemesi ${ }^{33}$ Salamis $\mathrm{Ha}-$ mamı'nda işlevi farklı olsa da ${ }^{34}$, söz konusu yapının planlaması ile benzerlikler göstermektedir. Bununla birlikte M.S. 1. - 2. yüzyıla tarihlenen Lykia hamamlarından Arykanda büyük hamam-gymnasium kompleksi ${ }^{35}$, Kadyanda Vespasian Hamami ${ }^{36}$, Kyaneae Antoninus Pius hama-

30 De Vos 1982, 296 vd.; Yegül 1992, fig. 63; Nielsen 1993, 7.

31 Paschetto 1912, 265; Krencker 1929, 259, Abb. 390; Meiggs 1973, 409 vd.; Pavolini 1983, 55 vd.; Nielsen 1993, 5, fig. 66.

32 Becatti 1953, 138 vd.; Pavolini 1983, 120; Nielsen 1993, 5, fig. 65.

33 Farrington 1995, 3 vd.

34 Bölümün çevresinde yapılan kazılarda, bu bölümü ısıtan ikinci bir külhana rastlanmamıștır. Tepidarium I'de ayaklar temizlendikten ve nişlerde kirden arındırildıktan sonra sıcağa dayanıksız insanların çok sıcak olan caldarium yerine bu bölümü kullandıkları söylenebilir. Zira tek külhanın hem caldarium'u hem de bu bölümü aynı derecede 1sıtması zordur, çünkü caldarium'u ısıtan sıcak hava bu bölüme gelinceye kadar 1sısını bir miktar kaybedecektir. Bununla birlikte fresklerin tepidarium II'de ele geçmesine rağmen caldarium'da görülmemesi de sıcaklık ve buhar nedeniyle bozulma riskinden dolayı olmalıdir. Caldarium'daki sıcak havayı tutmak için tonoz geçișlerde kullanılan kapılara ait dübeller de dikkati çekmektedir.

35 Bayburtluoğlu 1983, 277-283; Yegül 1992, 299; Farrington 1995, 150, fig. 2; Bayburtluoğlu 2003, 127.

36 Benndorf - Niemann 1883, 142,148; Kalinka 1920, 240-241; Wurster 1976, 31-32; Bean 1978, 44-45; Farrington 1995, 151-152, fig. 3. 
$\mathrm{mi}^{37}$, Patara Kuzey ${ }^{38}$ ve merkez hamam ${ }^{39}$, Tlos hamam $\mathrm{B}^{40}$ ve Oenoanda hamam Mk1 ${ }^{41}$ bu biçimdeki düzenlemeye örnek gösterilebilir. Anadolu'nun diğer bölgelerinden söz konusu hamam ile benzerlik gösteren, Phrygia bölgesindeki Hierapolis'ten hem planlama hem duvar işçiliği bakımından Freskli hamam ${ }^{42}$, Pamphylia bölgesinden Sillyon hamami ${ }^{43}$ planlamalarınin da Salamis Hamamı ile paralel özellikler göstermesine rağmen kentin bu yapısının bire bir örneği yoktur ve kent kendi planlama tipini oluşturmuş olmalıdır (Tablo 2) ${ }^{44}$. Kıbrıs'ta yer alan ve yayinlar dahilinde irdelenen Salamis

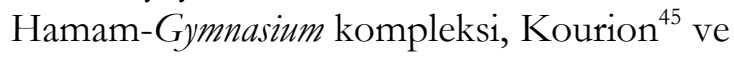
Nea Paphos'daki ${ }^{46}$ hamam, Amathonte hamami ${ }^{47}$ ile de planlama açısından tamamen farklıdır.

Söz konusu yapının hangi tarihte inşa edildiği konusunda bize kesin bilgi verebilecek yazılı belge bulunamamasına karşın, yapıyı planlama ve mimari özelliklerine, duvar işçiliğine ${ }^{48}$, kazılarda ele geçen küçük buluntulara, ortaya çıkarılan yazıtlara, Salamis

37 Kupke 1993, 13-16; Farrington 1995, 152, fig. 4.

38 Kalinka 1920, 142; Yegül 1992, 258, 299 vd., figs. 392393, 422 (Küçük Hamam); Farrington 1995, 158, fig. 18.

39 Kalinka 1920, 142; Farrington 1995, 157-158, fig. 23.

40 Wurster 1976, 34-35; Yegül 1992, 299-300, fig. 39; Farrington 1995, 162, fig. 20.

41 Ling - Hall 1981, 31-53; Yegül 1992, 258, 298, fig. 389; Farrington 1995, 155, fig. 6.

42 Humann 1898, 7; Yegül 1992, 262-263, figs. 316-317 (Barilika hamami); Farrington 1995, 168, fig. 48.

43 Farrington 1995, 171-172, fig. 62; Abbasoğlu 2004, 3, lev. 1 , res. 7.

44 Bu plan tipi hem İtalya hem de Anadolu'da özellikle M.S. 2. - 3. yy hamamlarında çok sık karşımıza çıkmaktadir.

45 Vessberg - Westholm 1956, 15-16, fig.11; Nielsen 1993, 40, fig.236.

46 Daszewski 1976, 194-206, figs. 1, 3.

47 Aupert 1996, 73, plan 1.

48 Yapının depo bölümünde yapılan kazılarda iki farklı duvar işçiliği dikkati çekmiştir ve bu nedenle yapının iki evresi olduğu söylenebilir.
Hamam-Gymnasium kompleksinin yapım evreleri ve burada ele geçen yazıtlardan edinilen bilgilere göre tarihleme ve ne kadar süre ile kullanıldığını tespit etme olanağımız olmuştur.

İtalya, Yunanistan, Kuzey Afrika, Anadolu gibi Roma hakimiyetindeki bölgelerde yayınlar dahilinde ulaşılabilen hamamlar planlama açısından incelendiğinde söz konusu yapı ile tamamen aynı olan bir örnek olmadığını söyleyebiliriz. Fakat hamam, hem genel planı açısından hem de sıcaklık bölümlerinin planları ile başta Roma Dönemi'nde öncü olarak kabul edilen ve Roma hâkimiyetindeki bölgelerde planları ve mimarisi örnek alınarak uygulanan İtalya'daki, özellikle Pompeii'de yer alan hamamlar olmak üzere; Anadolu'da ise Lykia, Pamphylia, Kilikia'daki hamamlar ile benzerlikler göstermesine rağmen, yapının dişarıdan bir örneği kopya etmediği, büyük oranda yerel özellikler taşıdığ1 ve bununla birlikte kentin kendi planlama tipini oluşturduğu söylenebilir.

Yap1, Roma Dönemi, özellikle M.S. 1.- 2. yy hamamları ile planlama açısından benzerlikler göstermektedir. Gerçekleştirilen kazılar sonrası ele geçen ve M.S. 2.3. yy'a tarihlenen ${ }^{49}$ iki yazıta rağmen, yapının inşa tarihi ve kimin yaptırdığına dair elimizde yazılı kesin veriler yoktur. Bunun dışında külhan ve depo bölümünde yap1lan kazilarda ele geçen en erken buluntular arasında Doğu Sigillatası A ve B parçaları, M.S. 1. - 3. yüzyıllarda Filistin ve Kıbrıs için tipik olan güveç parçaları, birinin tondosunda Nike kabartması olan, M.S. 1. yy'dan 2. yy'n sonuna kadar üretilen kandiller ve kandil parçaları sayılabilir.

49 Ç. Şahin tarafından incelenen, bir şiire ait mısraları içeren yazıtlar, M.S. 2. - 3. yy’a tarihlendirilmiştir. 
Erken buluntuların yanı sıra yapının mimari özellikleri ve duvar işçiliğgi incelendiğinde ilk evresinin Roma Dönemi olduğu söylenebildiği gibi, özellikle Traian ve Hadrian Dönemi'nde yeniden inşa edilen ve yapının yanı başında olan Salamis Hamam-Gymnasium kompleksi ile de mimari açıdan büyük ölçüde benzerlikler göstermektedir.

Salamis Hamam-Gymnasium kompleksinde ele geçen yazıtlarda, M.S. 76 - 77 depreminden sonra, Traian (M.S. 98 - 117) ve Hadrian (M.S. 117 - 138) dönemlerinde kentteki yapılarda büyük onarımların ve inşa faaliyetlerinin gerçekleştirildiği, hatta İmparator Hadrian'in kente hizmetlerinden dolay1 büyük sayg1 gördügü ve Salamis kentinin koruyucusu ve yardımseveri ilan edildiğinden bahsedilmektedir ${ }^{50}$. Bu yapılaşma faaliyetleri içerisinde kentin Roma Dönemi'nden itibaren gelişmesi ve nüfusun artması, önemli bir ticaret limanı olması nedeniyle kente gelip giden tüccarlar, yolcular, bunların dişında Traian ve Hadrian Dönemi'nde onarılıp genişletilen tiyatro, stadion ve palaestra gibi kamu yapılarının varlığı da düşünülürse kentte yer alan ve Hellenistik Dönem'de inşa edilen hamam-gymnasium kompleksinin arttk ihtiyac1 karşılayamaz duruma gelmesi kaçınılmaz olmuştur. Bu yüzden kente, bu kamu yapılarina yakın ikinci bir hamam yapilması ihtiyac1 duyulmuş ve yap1, planlaması, mimari özellikleri, ele geçen buluntular da göz önünde bulundurulduğunda M.S. 2. yüzyılın ilk yarısında, Traian ya da Hadrian Döneminde inşa edilmiş olmalıdır.

Salamis Hamamı, kentteki diğer kamu yapıları gibi şehre büyük zarar veren M.S. 332 ve 342 y1llarındaki iki büyük deprem

50 Karageorghis 1969, 185. sonrası büyük oranda onarılmıștır ${ }^{51}$. Kazılar sonrası buluntuların büyük bir kısmı bu tarihten sonraya aittir ve yapının şu anda ayakta kalan ve açığa çıkarılan bölümleri büyük oranda söz konusu II. evreye verilebilir. Hamamin M.S. 647-648 Arap istilalarına kadar kullanıldığı da kazılarda ele geçen buluntularla desteklenmektedir (Res. 17-18). Hamam ve çevresinde gerçekleştirilen kazılarında ele geçen düz, kapama ve damgalı kiremitler, geç dönem seramikler ve yapının içinde ele geçen kandiller, İmparator Herakleios (M.S. 610-641) sikkeleri ${ }^{52}$ hamamin deprem sonrası onarıldıktan sonra da kullanıldı̆̆ının göstergesi olduğu gibi, bazı bölümlerinde görülen onarım izleri, mimari yapisı ve kullanilan opus sectile'ler de yap1nın Arap istilalarına kadar kullanıldığına işarettir.

51 Roma döneminde Kıbrıs'ın çok şiddetli depremlerle sarsıldığ bilinmektedir. Bunlardan M.S. 77 yllındaki deprem sonrasi, kente imparator Traian ve Hadrian yardımlarda bulunmuş ve onarımlar yaptırmıştır. Diğer büyük deprem M.S. 332 ve 342 yıllarında meydana gelmiştir. Özellikle M.S. 4. yüzyılda meydana gelen depremler Salamis'i tamamen yıkmış ve şehrin büyük bir kısmı deniz alında kalmıştır. İmparator II. Constantius (M.S. 337 - 361) şehri yeniden inşa edilebilmeleri için, kent halkını dört yıl süreyle her türlü vergiden muaf tutmuș ve onarımlara destek vermiştir. Salamis'te daha küçük ölçekte kurulan bu yeni Hıristiyan kentinin adı imparatorun onuruna Constantia olarak değiştirilmiştir, Karageorghis 1969, 197-198; Karageorghis 1982, 187, 189. Salamis Hamamı da iki büyük deprem sonrasında tüm şehrin onarımina destek veren II. Constantinius tarafindan onartılmış olmalıdır.

52 Yapının sıcaklık bölümlerinde, atık su kanallarında ve yapı çevresinde İmparator Herakleios sikkeleri ele geçmiştir. $\mathrm{Bu}$ sikkelerin tarihlenmesinde yardımc1 olan Sayın Zeynep Çizmeli Öğün'e teşekkürü bir borç biliyorum. 
Arş. Gör. Aytaç Coşkun (M.A.)

Dicle Üniversitesi

Fen-Edebiyat Fakültesi

Arkeoloji Bölümü

21280 Diyarbakır

e-mail: aytaccoskun@hotmail.com

\section{Çizim ve Levhaların Listesi:}

Harita 1. Salamis'in konumu (A. Coşkun).

Plan 1. Salamis kent plan1.

Resim 1. Kamu Yapıları 1998 (C. Özgünel).

Resim 2. Roma Hamamı Planı (A. Coşkun).

Resim 3-4. Hamam ve cadde rekonstrüksiyon (A. Coşkun).

Resim 5. Geçiş mekanı - rekonstrüksiyon (A. Coşkun).

Resim 6-7. Tonoz tuğlası üzerinde görülen fresk parçaları.

Resim 8-9. Tepidarium I bölümü - rekonstrüksiyon (A. Coşkun).

Resim 10. Tepidarium II apsidal havuz.

Resim 11. Tepidarium II rekonstrüksiyon (A. Coşkun).

Resim 12. Tepidarium II dikdörtgen havuz - rekonstrüksiyon (A. Coşkun).

Resim 13. Caldarium oval havuz - rekonstrüksiyon (A. Coşkun).

Resim 14. Praefurnium bölümü.

Resim 15. Praefurnium rekonstrüksiyon (A. Coşkun).

Resim 16. Depo bölümü - rekonstrüksiyon (A. Coşkun).

Resim 17-18. Roma Hamamı rekonstrüksiyon (A. Coşkun). 


\begin{tabular}{|c|c|c|c|c|}
\hline Yap1 & Duvar Tekniği & Tarihi & Yönü & Kapladığı Alan \\
\hline $\begin{array}{l}\text { Herculaneum } \\
\text { Forum hamamı }\end{array}$ & $\begin{array}{l}\text { Opus reticulatum, opus } \\
\text { mixtum }\end{array}$ & $\begin{array}{l}\text { Erken Augustus - Claudius } \\
\text { (M.S. 41-54) M.S. 79'da } \\
\text { y1k1ldı. }\end{array}$ & Güneybat1 & $650 \mathrm{~m}^{2} ; 1780 \mathrm{~m}^{2}$ \\
\hline $\begin{array}{l}\text { Ostia'daki } \\
\text { Neptune hamamı }\end{array}$ & Opus testaceum & $\begin{array}{l}\text { Hadrian (M.S. 117-138), } \\
\text { yapıy1 M.S. 139'da Antoninus } \\
\text { Pius bitirdi. Marcus Aurelius } \\
\text { (M.S. 161-180) tarafindan } \\
\text { onarild1. }\end{array}$ & Güneybat1 & $2300 \mathrm{~m}^{2}$ \\
\hline $\begin{array}{l}\text { Ostia Mitra } \\
\text { hamamı }\end{array}$ & $\begin{array}{l}\text { Opus testaceum, opus } \\
\text { vittatum }\end{array}$ & $\begin{array}{l}\text { Hadrian, Severus } \\
\text { Dönemi'nde (M.S. 193-211) } \\
\text { onarıldı, 4. yüzyılın II. } \\
\text { yarısında yeniden inşa edildi. }\end{array}$ & Güneybat1 & $1100 \mathrm{~m}^{2}$ \\
\hline $\begin{array}{l}\text { Pompei Stabian } \\
\text { hamami }\end{array}$ & Opus incertum & $\begin{array}{l}\text { M.Ö. 5. yy; M.Ö. 2. yüzyıl, } \\
\text { M.Ö. 80-50, Augustus (M.Ö. } \\
27 \text { - M.S. 14) ve M.S. 62'de } \\
\text { genişletilerek daha büyük inşa } \\
\text { edildi. M.S. 79'da yıkıldı. }\end{array}$ & Güneybat1 & $\begin{array}{l}\text { Illk evre } 1050 \mathrm{~m}^{2} \\
3000 \mathrm{~m}^{2}\end{array}$ \\
\hline $\begin{array}{l}\text { Pompei merkez } \\
\text { hamam }\end{array}$ & $\begin{array}{l}\text { Opus incertum, opus } \\
\text { testaceum }\end{array}$ & Bitirilememiş, M.S. 62-79. & Güneybatı & $1700 \mathrm{~m}^{2} ; 3500 \mathrm{~m}^{2}$ \\
\hline
\end{tabular}

Tablo 1. İtalya'dan Salamis Hamamı ile paralel ‘sıra tipi’ planlı Roma Hamamları

\begin{tabular}{|c|c|c|c|c|}
\hline Yap1 & Duvar Tekniği & Tarihi & Yönü & Kapladığı Alan \\
\hline $\begin{array}{l}\text { Arykanda Büyük } \\
\text { hamam-gymnasium } \\
\text { kompleksi }\end{array}$ & Polygonal & M.S. 2. yüzy1l & Güney & $2849 \mathrm{~m}^{2}$ \\
\hline $\begin{array}{l}\text { Kadyanda } \\
\text { Vespasian } \\
\text { hamamı }\end{array}$ & Polygonal & M.S. 69-79 & Güney & $1190 \mathrm{~m}^{2}$ \\
\hline $\begin{array}{l}\text { Kyaneae } \\
\text { Antoninus Pius } \\
\text { hamamı }\end{array}$ & Polygonal & M.S. 139-142 & Güney & $620 \mathrm{~m}^{2}$ \\
\hline $\begin{array}{l}\text { Oenoanda } \\
\text { hamam Mk1 }\end{array}$ & Polygonal & M.S. 2. yüzy1l? & Kuzeybat1 & $690 \mathrm{~m}^{2}$ \\
\hline $\begin{array}{l}\text { Patara Kuzey } \\
\text { hamam }\end{array}$ & Opus quadratum & M.S. 2. - Erken 3. yüzy1l? & Güney & $610 \mathrm{~m}^{2}$ \\
\hline $\begin{array}{l}\text { Patara Merkez } \\
\text { hamam }\end{array}$ & $\begin{array}{l}\text { Polygonal, Opus } \\
\text { vittatum }\end{array}$ & $\begin{array}{l}\text { İlk evre M.S. } 68 \text { - 2. yüzyıl?; } \\
\text { İkinci evre Geç İmparatorluk } \\
\text { - Bizans? }\end{array}$ & Güney & $775 \mathrm{~m}^{2}$ \\
\hline Tlos hamam B & $\begin{array}{l}\text { Opus quadratum, } \\
\text { Polygonal }\end{array}$ & M.S. 2. - Erken 3. yüzy1l? & Güneybat1 & $800 \mathrm{~m}^{2}$ \\
\hline $\begin{array}{l}\text { Hierapolis Freskli } \\
\text { hamam }\end{array}$ & Opus quadratum & $?$ & Güneybat1 & $3300 \mathrm{~m}^{2}$ \\
\hline Sillyon hamamı & Opus quadratum & İmparatorluk (yap1 tipi) & Kuzeybat1 & $800 \mathrm{~m}^{2}$ \\
\hline
\end{tabular}

Tablo 2. Anadolu'dan Salamis Hamamı ile paralel 'sıra tipi' planlı Roma Hamamları 


\section{KAYNAKÇA}

Abbasoğlu 2004

Aupert 1996

Bayburtluoğlu 1983

Bayburtluoğlu 2003

Bean 1978

Becatti 1953

Benndorf - Niemann 1883

Brödner 1983

Coşkun 2007

Daszewski 1976

De Vos 1982

Farrington 1995

Fiorelli 1875

Guide 1970

Humann - Cichorius 1898

Jeffery 1926

Kalinka 1920

Karageorghis 1962

Karageorghis 1963

Karageorghis 1969

Karageorghis 1970

Karageorghis 1982

Krencker 1929

Kupke 1993
H. Abbasoğlu, "Pamphylia Hamamları: Plan Açısından Bir Değerlendirme”, 60. Yaşında Fahri Işık'a Armaŭan Anadolu'da Doğdu I Festschrift für Fabri Işlk zum 60. Geburtstag (2004) 1-9.

P. Aupert, Guide D'Amathonte (1996).

C. Bayburtluoğlu, “Arykanda 1982”, KST 4, 1983, 277-284.

C. Bayburtluoğlu, Arykanda (2003).

G. E. Bean, Lycian Turkey: An Archaeological Guide (1978).

G. Becatti, Scavi di Ostia I. Parte seconda. Lo sviluppo urbanistico (1953).

O. Benndorf - G. Niemann, Reisen in Lykien und Karien (1883).

E. Brödner, Die Römischen Thermen und das Antike Badewesen (1983).

A. Cosskun, "On the Planning and Dating of the Roman Bath at Salamis, Cyprus", E. Öztepe - M. Kadığlu (derl.), Patronvs. Coşkun Özgünel'e 65. Yas Armağan / Festschrift für Coşkun Özgünel zum 65. Geburtstag (2007) 123-132.

W. A. Daszewski, "Les Fouilles Polonaises A Nea Paphos 1972-1975 Rapport Preliminaire”, RDAC, 1976, 185-225.

A. De Vos - M. De Vos, Pompei: Ercolano, Stabia. Guide archeologiche Laterza (1982).

A. Farrington, The Roman Baths of Lycia. An Architectural Study (1995).

G. Fiorelli, Descrizione di Pompeji (1875).

Cyprus Department of Antiquities, "Salamis A Guide" (1970).

K. Humann - C. Cichorius, Altertümer von Hierapolis (1898).

G. Jeffery, The Ruins of Salamis (1926).

E. Kalinka, "Tituli Lyciae linguis Graeca et Latina conscripti", TAM 2 (1920).

V. Karageorghis, "Fouilles de Salamine”, BCH 86, 1962, 396-405.

V. Karageorghis, "Excavations at Salamis, 1963", RDAC, 1963, 5255.

V. Karageorghis, Salamis Recent Discoveries in Cyprus (1969).

V. Karageorghis, "Salamis auf Zypern”, $A W$ 1, 1970, 3-15.

V. Karageorghis, Cyprus From the Stone Age to the Romans (1982).

D. Krencker - E. Krüger - H. Lehmann - H. Wachtler, Die Trierer Kaiserthermen (1929).

B. Kupke, "Arbeiten in Stadtgebiet von Kyaneai", içinde: F. Kolb (derl.), Die Siedlungskammer von Kyaneai in Lykien, Lykische Studien I, AsiaMS 9 (1993) 10-23. 
Ling - Hall 1981

Maiuri 1942

Meiggs 1973

Munro - Tubbs 1907

Nielsen 1993

Nissen 1877

Öztaner 2007

Paschetto 1912

Pavolini 1983

Vessberg - Westholm 1956

Wurster 1976

Yegül 1992
R. J. Ling - A. Hall, "Building Mk 1 at Oenoanda", AnatSt 31, 1981, 31-53.

A. Maiuri, L’Ultima fase edilizia di Pompei (1942).

R. Meiggs, Roman Ostia (1973).

J. A. R. Munro - H. A. Tubbs, "Excavation in Cyprus 1890, Third Season's Work, Salamis”, JHS 12, 1907, 59-198.

I. Nielsen, Thermae et Balnea: The Architecture and Cultural History of Roman Public Baths (1993).

H. Nissen, Pompeianische Studien zur Stadtekunde des Altertums (1877).

H. Öztaner, "Salamis Sütunlu Caddesi, 'Özgünel Yolu”, E. Öztepe M. Kadioğlu (derl.), Patronvs. Coşkun Özgünel'e 65. Yaş Armağanı / Festschrift für Coskun Özgünel zum 65. Geburtstag (2007) 293-306.

L. Paschetto, Ostia. Colonia Romana. Storia e monumenti (1912).

C. Pavolini, Ostia. Guide archeologiche Laterza (1983).

O. Vessberg - A. Westholm, "The Hellenistic and Roman Periods in Cyprus”, The Swedish Cyprus Expedition, IV.3 (1956).

W. Wurster, "Antike Siedlungen in Lykien. Vorbericht über ein Survey - Unternehmen”, AA 1976, 23-49.

F. K. Yegül, Baths and Bathing in Classical Antiquity (1992). 

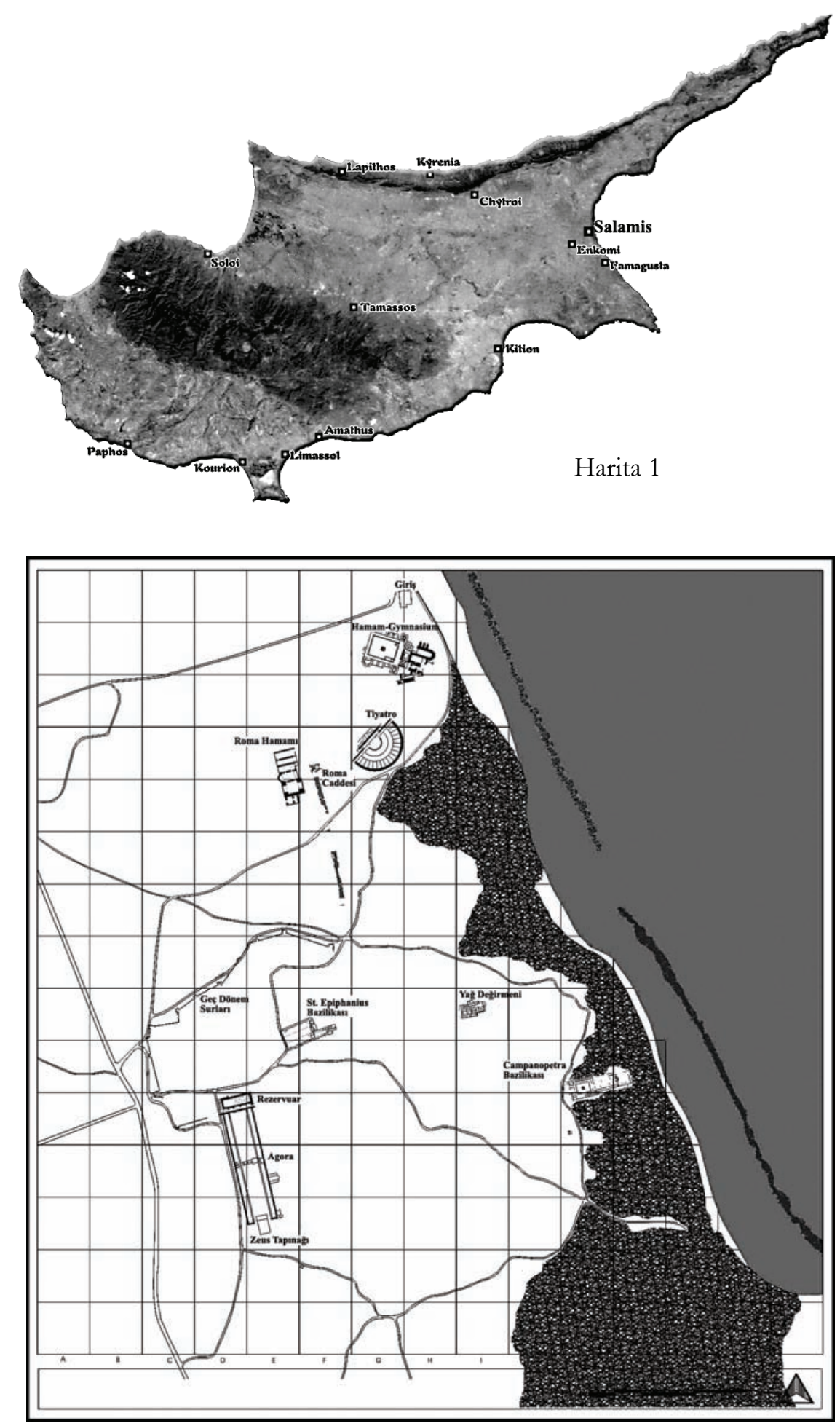

Plan 1 


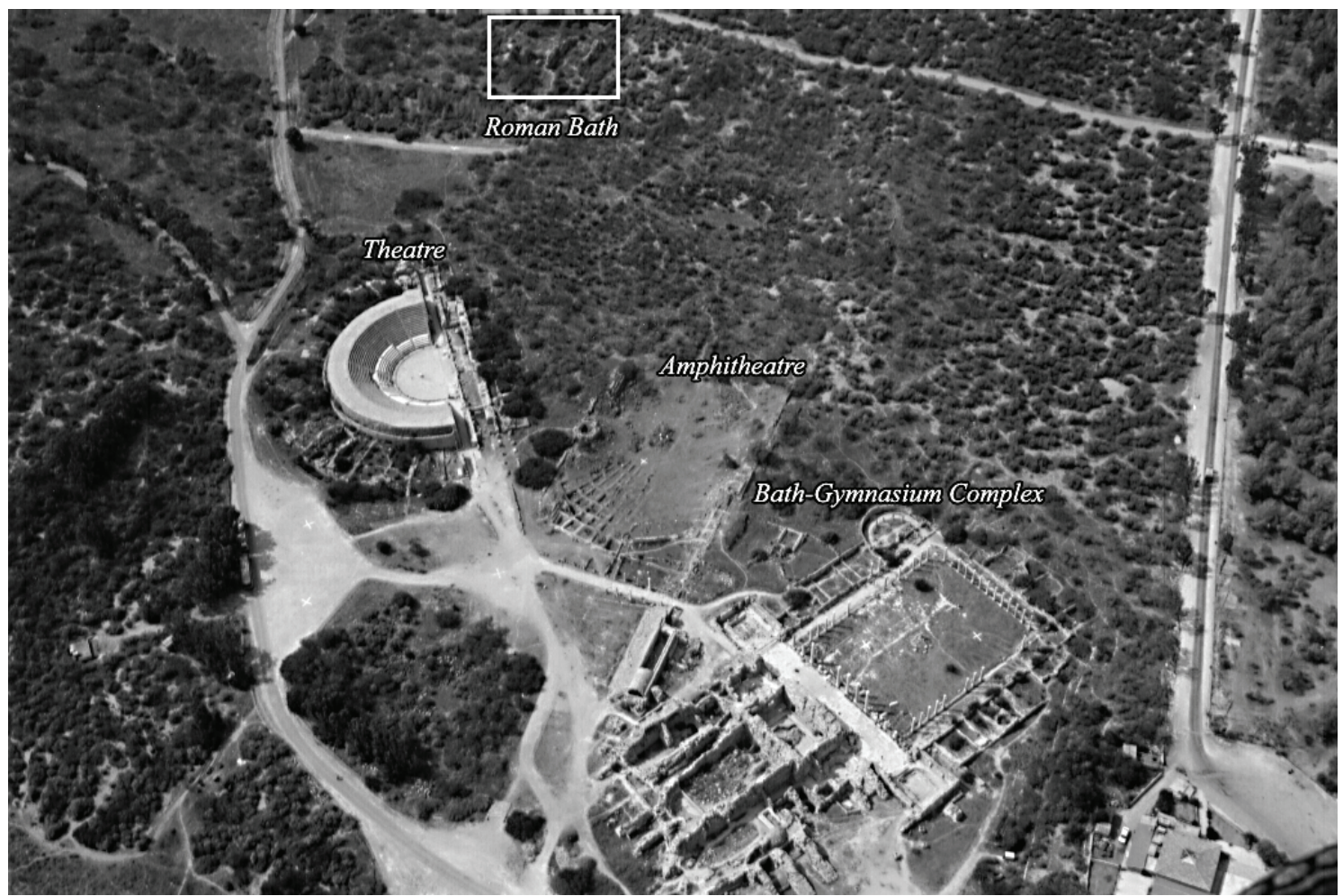

Resim 1

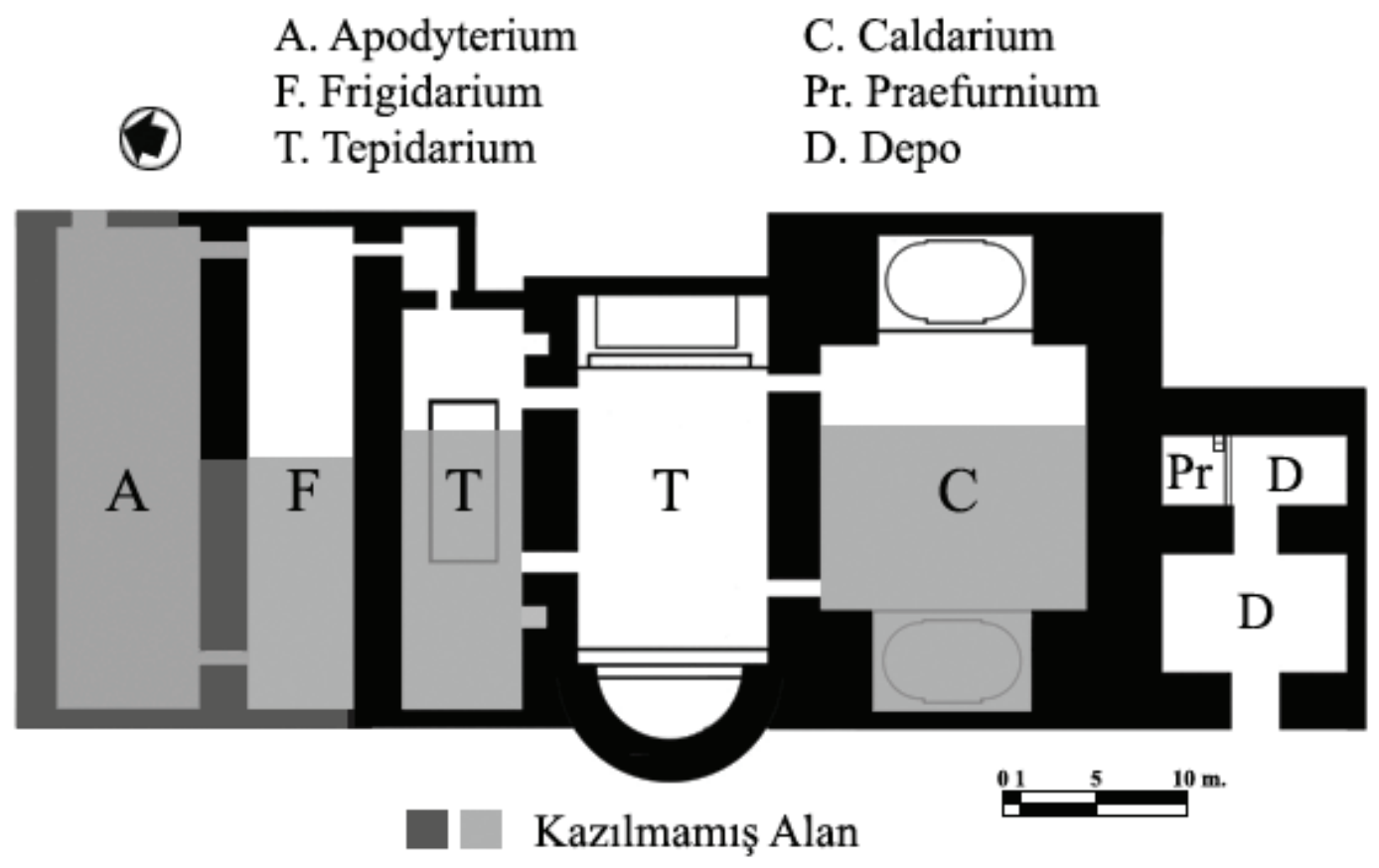




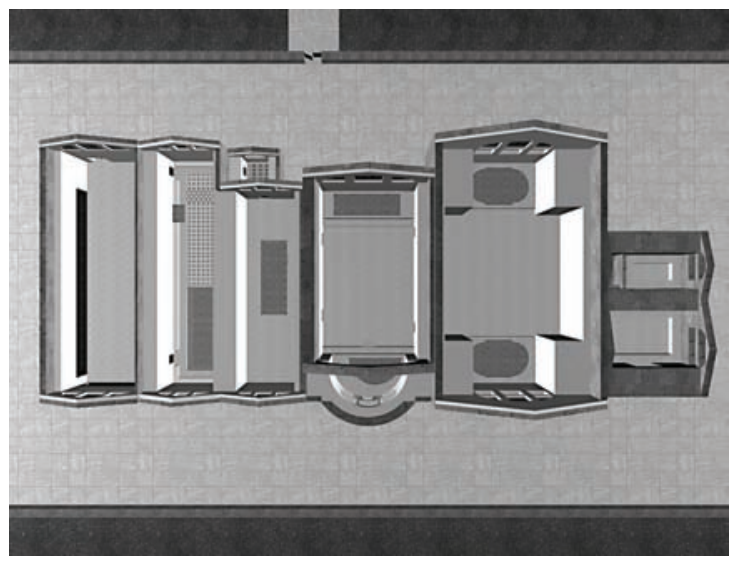

Resim 3

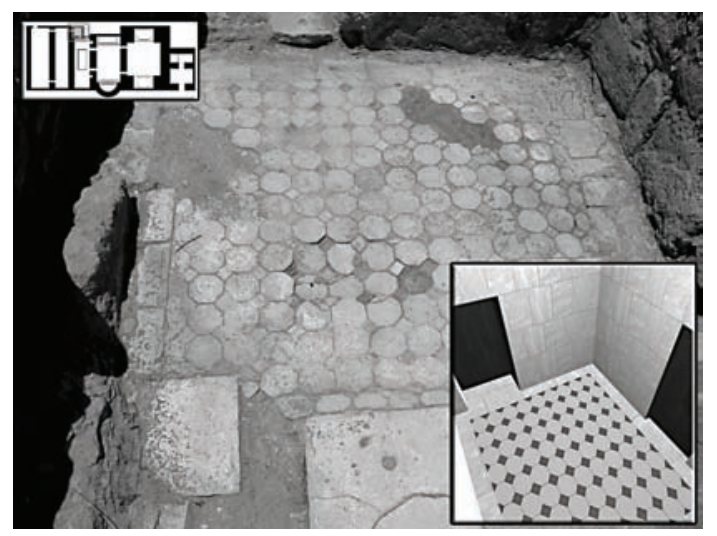

Resim 5
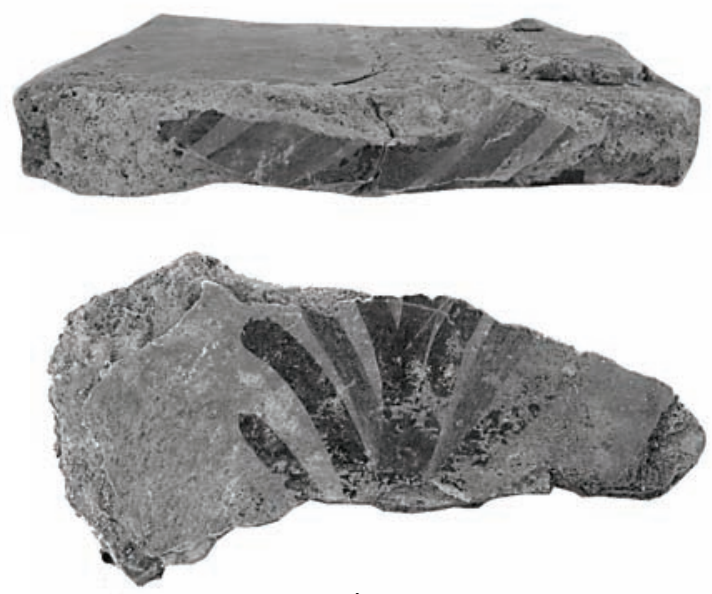

Resim 7-8

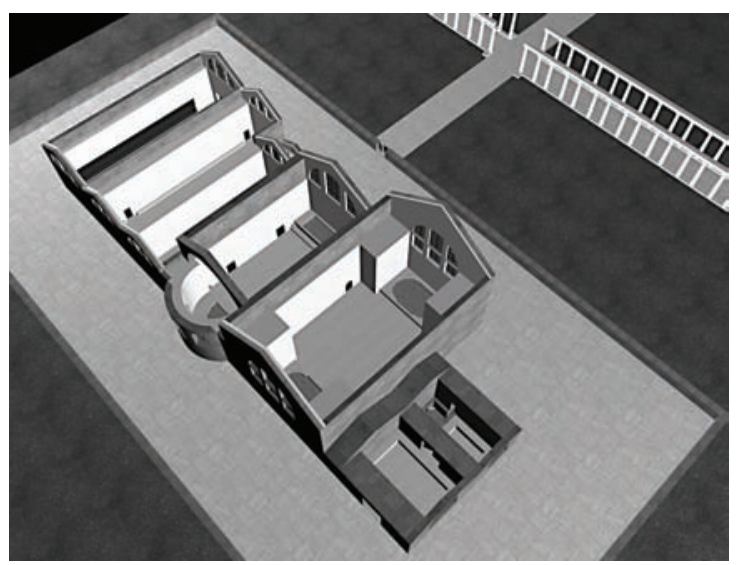

Resim 4

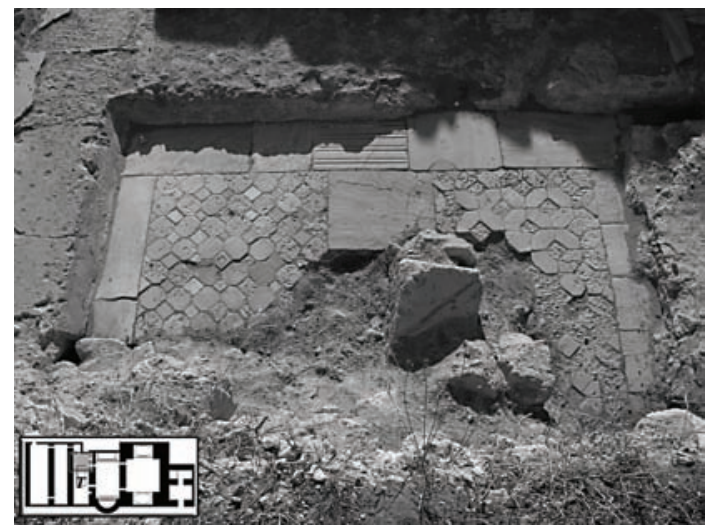

Resim 6

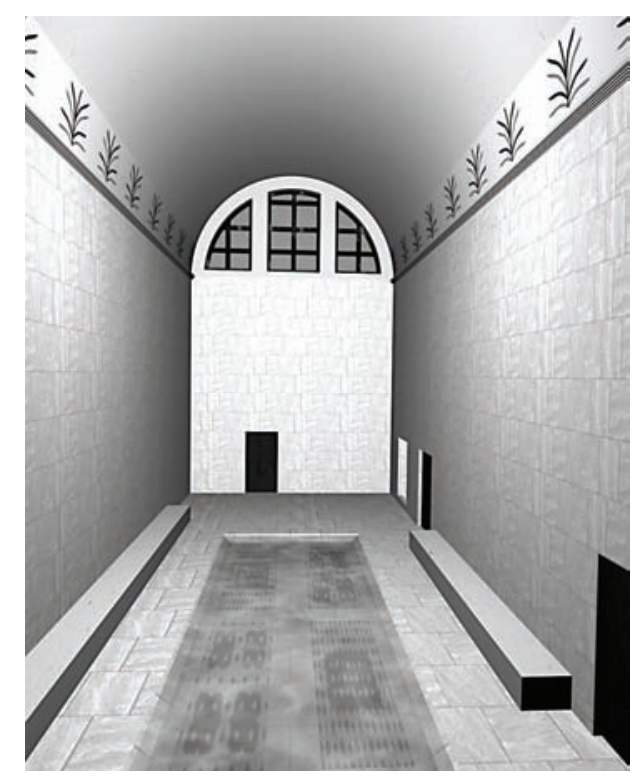




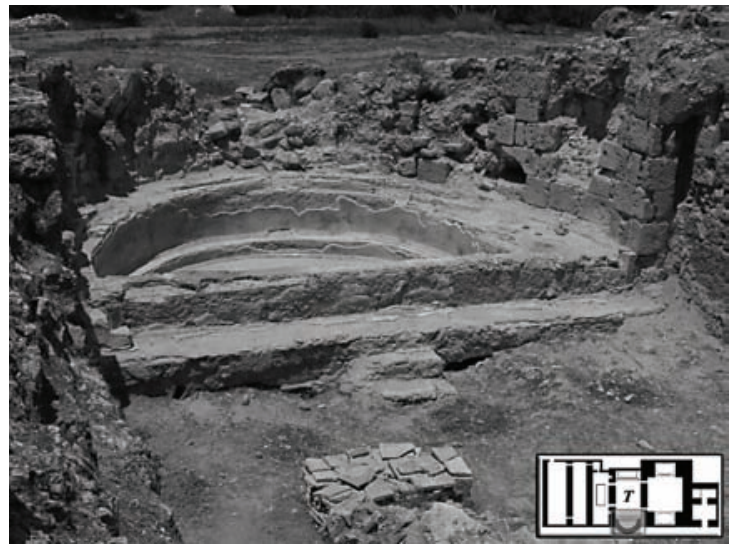

Resim 10

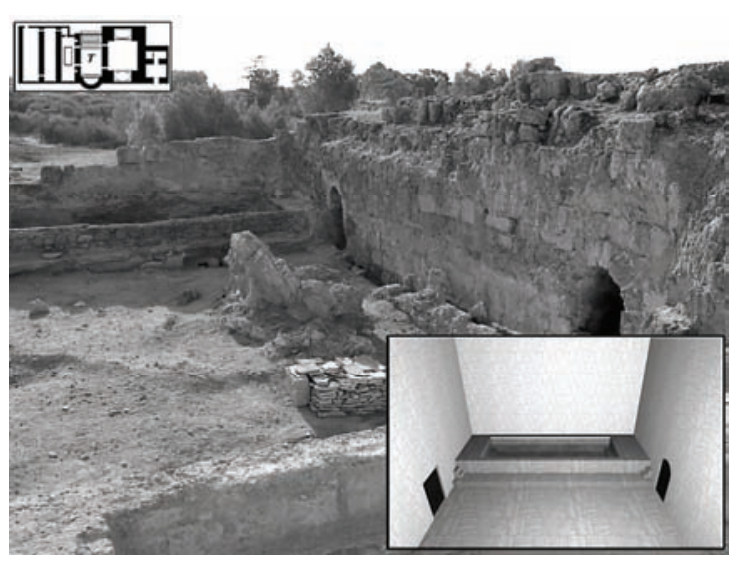

Resim 12

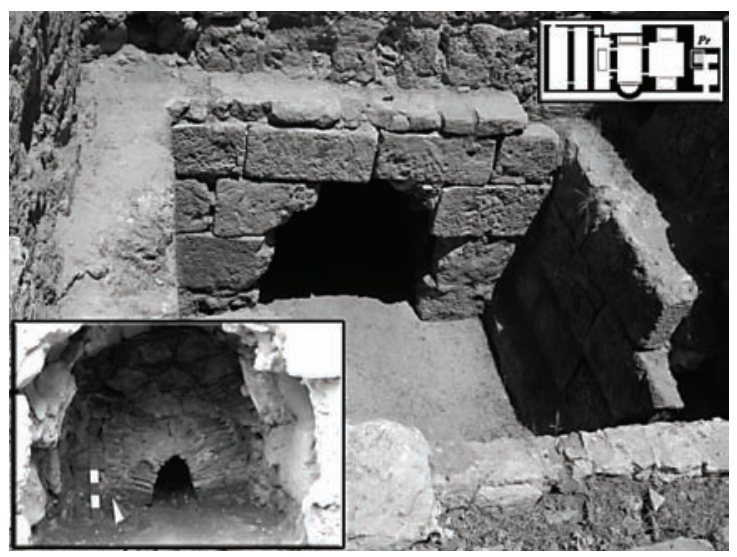

Resim 14

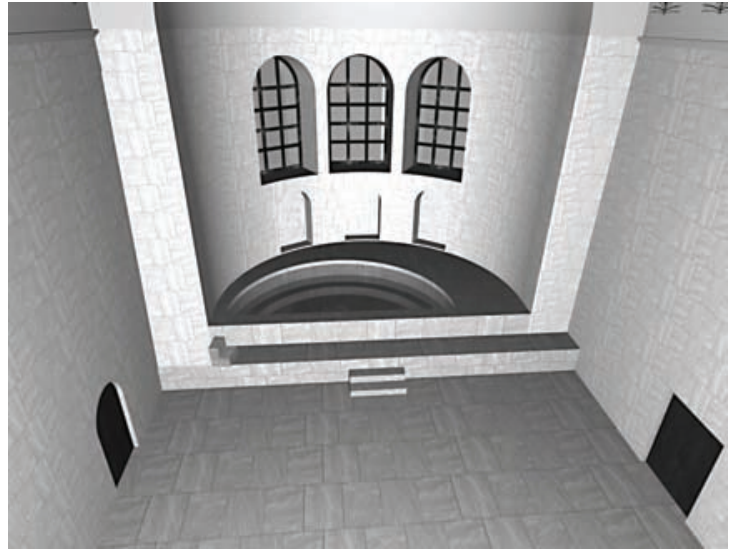

Resim 11

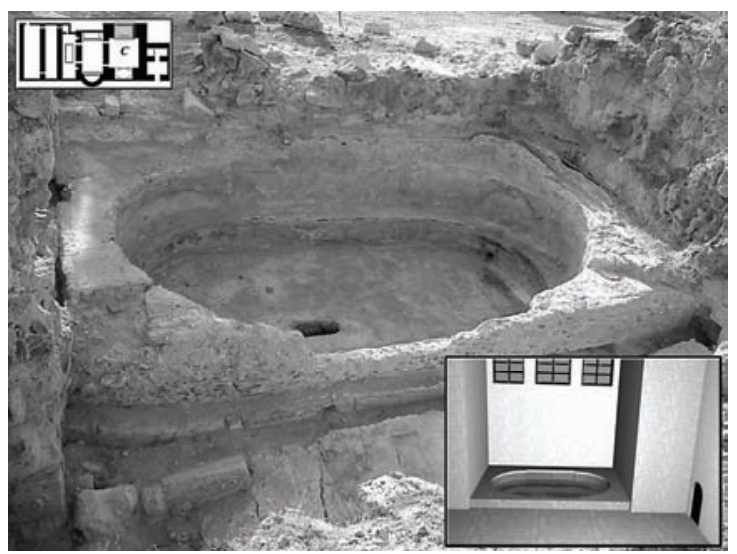

Resim 13

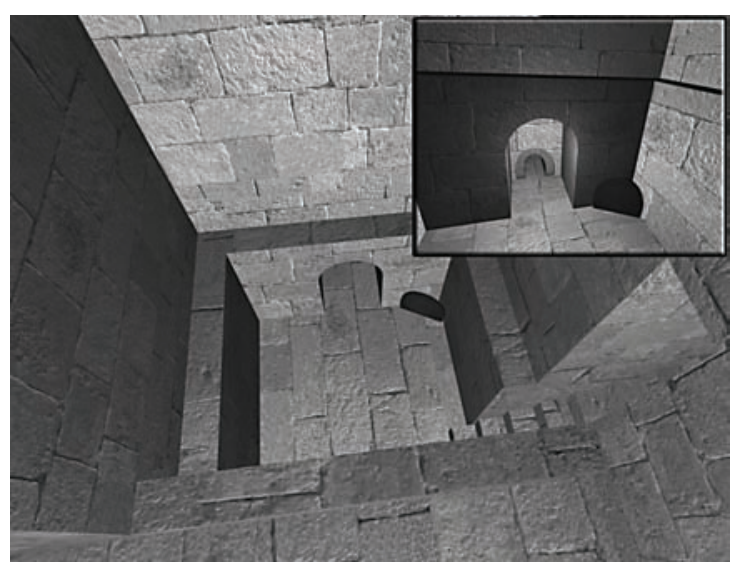

Resim 15 


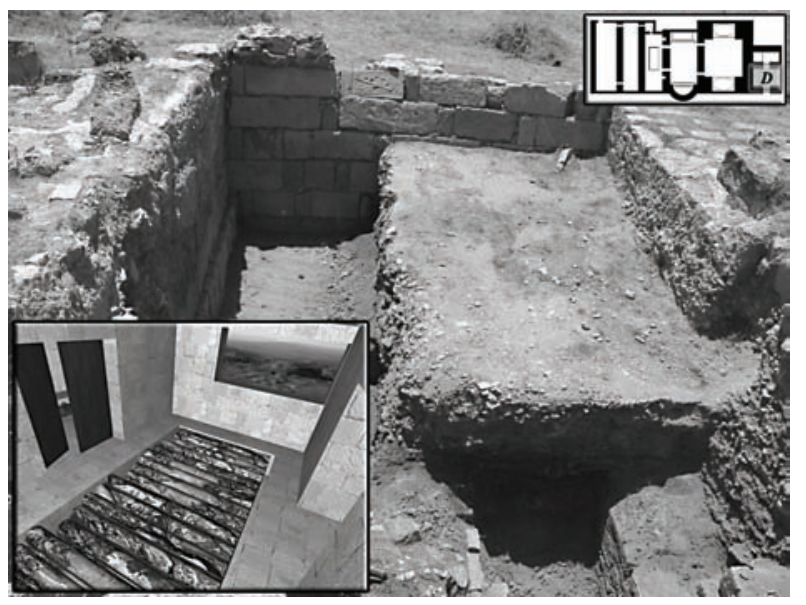

Resim 16

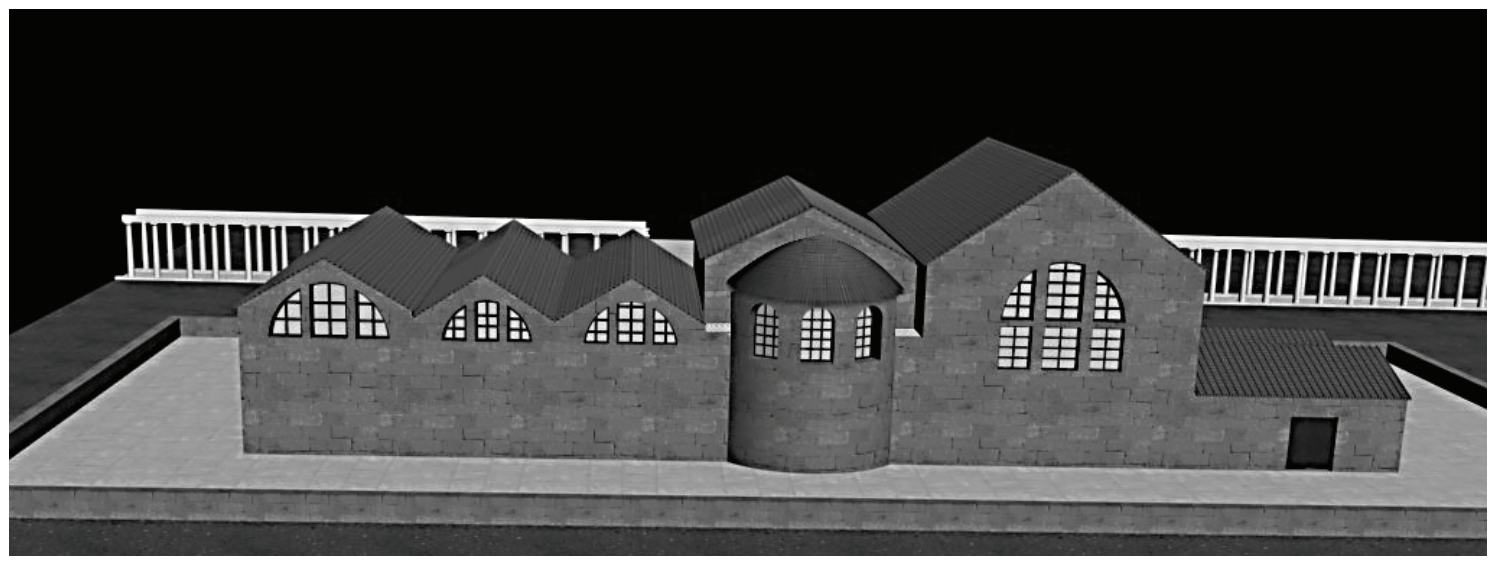

Resim 17

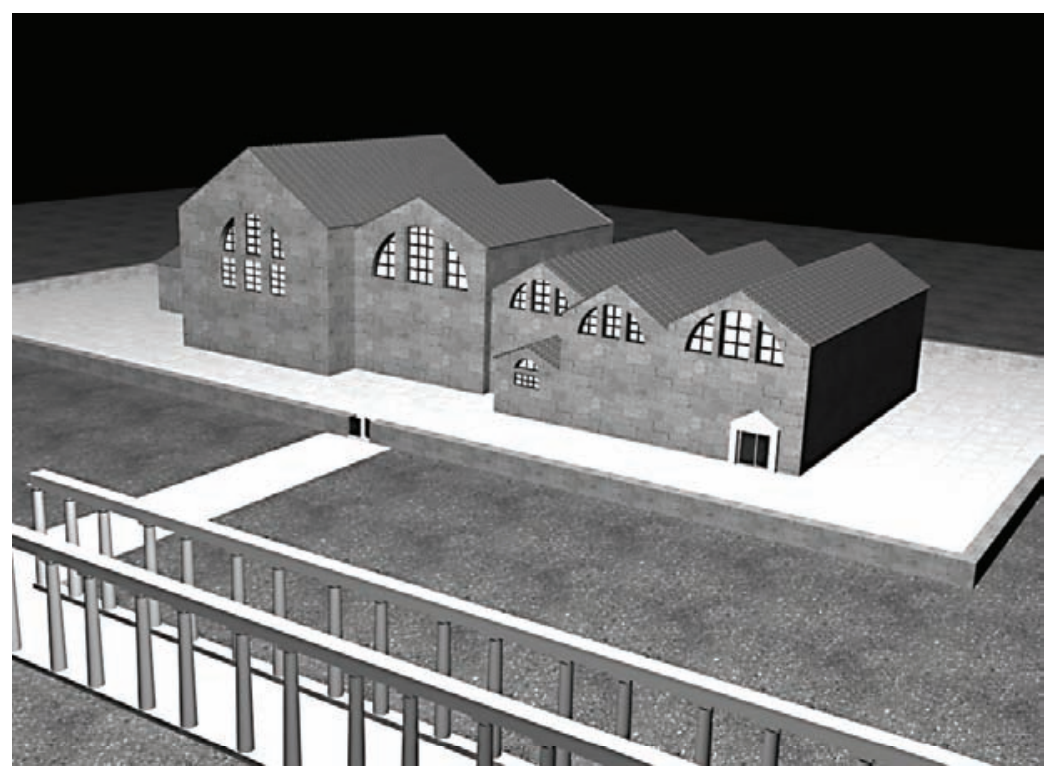

Resim 18 